\title{
Simple and Sustainable Constipate to Save Cost and Time for Structure Constructions
}

\author{
Abdualraouf Mohamed*, Mohamed Ali Milad \\ Department of Civil Engineering, College of Engineering, Elmergib University, Libya \\ DOI: https://doi.org/10.21467/proceedings.4.4 \\ * Corresponding author email: raouf.amhir@gmail.com
}

\begin{abstract}
The energy required producing the structural elements such as concrete, steel; wood, etc. have serious environmental and financial consequences. The energy analysis, therefore, must take into consideration the added cost of embodied energy, which is the energy consumed by all of the processes associated with the production of a building. Generally, highly processed material, the higher embodied energy is. Hence, concrete has the lowest re-use capability that makes it a less sustainable material. Thus, wisely, use construction material leads to avoid the use of materials that are associated with high-embodied energy. Moreover, choosing the optimal construction system is one of the elementary bases of sustainability through the possibility of recycling the materials used for building construction. This study presents guidance of the sustainable constipates based on the performance of building construction using masonry barring walls system against frame concrete structure system of residential buildings, Where finite element method was used to analyze the stresses on the masonry bearing walls, and structural analysis for the frame structure. Algebra calculation of the construction materials quantities, and known sources of embodied energy estimation. As a result, this comparison turns out that the masonry barring walls system procedure is offering good distribution of stresses, more economical, require lesser time to build, and highly recyclable, which making it more contributing to sustainability.
\end{abstract}

Keywords: Embodied energy, Sustainability, Masonry, Recycling, Construction

\section{Introduction}

The cost of structural elements of concrete construction work and materials used in the traditional methods of construction in the State of Libya may be high; some of it is not environmentally friendly. Moreover, the lack of natural resources for these materials and the high-embodied energy in their production and taking into account the non-use of sustainability methodology in construction makes us think more careful and thoughtful about the techniques used in construction in the State of Libya. In the construction of simple residential buildings, there is known two major structural systems: concrete rigid frame structure system; and masonry wall bearing system and there is great differences in the characteristics of each system [1]. Each has its advantages and disadvantages [2,3]. Nevertheless, the concern is the

(C) 2018 Copyright held by the author(s). Published by AIJR Publisher in Proceedings of First Conference for Engineering

Sciences and Technology (CEST-2018), September 25-27, 2018, vol. 2.
This is an open access article under Creative Commons Attribution-NonCommercial 4.0 International (CC BY-NC 4.0)

license, which permits any non-commercial use, distribution, adaptation, and reproduction in any medium, as long as the original work is properly cited. ISBN: 978-81-936820-6-7 
technique and performance of building that built according to these systems in the State of Libya at current era. Because of the method of implementation, where in realty construction is a mixed system between these two systems due to the embodied the concrete masonry into the rigid concrete frame. This method of construction might accidentally give very large capacity of the structural system compared to the capacity required, which leads to a noneconomic building and is not sustainable for its more embodied energy and the effort of recycling materials used by the end of building's life span. On the other words, the presence and implementation of concrete masonry within the concrete rigid frame makes it an effective factor to carry forces and even change the behaviour of loads path. As result of mixing these two systems is a complex system that capable of resisting more than is required to resist. Nevertheless, unfortunately there is no need here to increase the capacity because the frame system designed to bear the whole loads alone. However, the main difference between the two systems is the mechanism of carrying loads safely through itself to the ground soil. Standers and cods commends that the characteristics of each of these structural systems individually and do not see the need to mix these two systems together because each of them is well alone $[4,5]$. However, the reality of the situation in the State of Libya in the construction of simple private housing buildings, which mix these two systems made it important to know the advantages and disadvantages of this system to help the Libyan citizen to choose the optimal system to build his house in economic and sustainable way. Hence, the idea of this study evaluates the structural performance, and sustainability efficiency of each system then examines the effect mixing them [6]. Moreover, this study illustrates the behaviour of each of these known structural systems and simulate the system used extensively in the construction in the state of Libya, also compared between different systems in terms of stresses distribution, the amount of materials used, embodied energy, then evaluating these systems in terms of sustainability principle. The following sections demonstrate the method and the primary variables, then evaluates the results and present the conclusion.

\section{Material and Research Methodology}

The research studies a typical residential concrete building with components in line with the tradition and housing requirements of a middle-income family in Libyan society. It is singlestory building of 165-square-meter footage print; Figure 1 shows the plan and $3 \mathrm{D}$ views of the house. 3D models of structural analysis were prepared for three structural systems. The first model is concrete rigid frame model and analyzed as line element by structural analysis method, the second model is masonry wall bearing and analyzed as surface element by finite element methods; the third is the mixed system model (concrete rigid frame and masonry wall bearing). Modeling and analysis are carried out using SAP 2000, Figure 2 shows the models as it appears on SAP 2000. Table 1 shows the characteristics of the materials used, and Table 2 shows the loads were applied [7]. Where these values simulate the properties of the materials used in practice and the application of standards and specifications in the Libyan state.

Proceedings of First Conference for Engineering Sciences and Technology (CEST-2018), vol. 2 


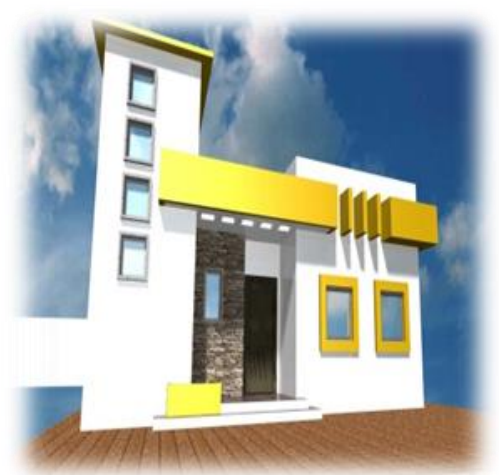

(a)

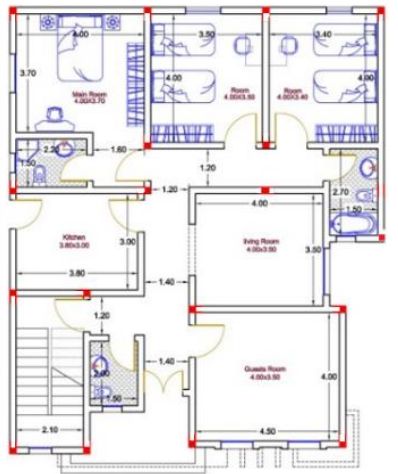

(b)

Figure 1: (a) house plan view, (b) house 3D view

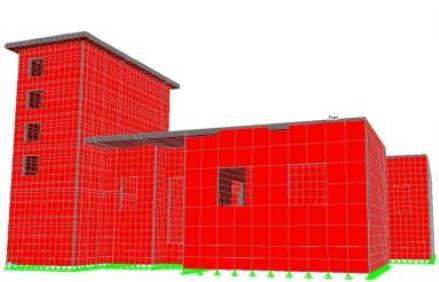

(a)

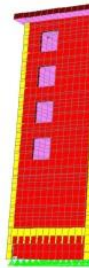

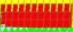

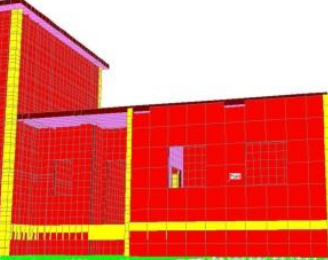

(c)

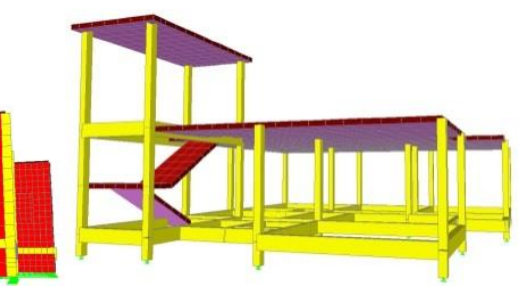

(b)

Figure 2: (a) Concrete rigid frame model, (b) Masonry wall bearing model, (c) Mixed model

Table 1: Characteristics of materials for analysis and design

\begin{tabular}{|c|c|}
\hline Material property & The value \\
\hline Concrete $\left(\mathrm{fc}^{\prime}\right)$ & $28 \mathrm{MPa}$ \\
\hline Rebar $(\mathrm{fy})$ & $280 \mathrm{MPa}$ \\
\hline Reinforced concrete density & $24 \mathrm{kn} / \mathrm{m}^{3}$ \\
\hline Masonry concrete density & $20 \mathrm{kn} / \mathrm{m}^{3}$ \\
\hline
\end{tabular}

Table 2: Applied loads, dead and live

\begin{tabular}{|r|c|c|c|}
\hline $\begin{array}{r}\text { Model } \\
\text { Load type }\end{array}$ & Model 1 & Model 2 & Model 3 \\
\hline $\begin{array}{c}\text { Self-weight of } \\
\text { structural elements }\end{array}$ & SAP Calculated & SAP Calculated & SAP Calculated \\
\hline Finishes loads on roof & $2.50 \mathrm{kn} / \mathrm{m}^{2}$ & $2.50 \mathrm{kn} / \mathrm{m}^{2}$ & $2.50 \mathrm{kn} / \mathrm{m}^{2}$ \\
\hline Wall loads & $12 \mathrm{kn} / \mathrm{m}$ & SAP Calculated & SAP Calculated \\
\hline Live load on roof & $3 \mathrm{kn} / \mathrm{m}^{2}$ & $3 \mathrm{kn} / \mathrm{m}^{2}$ & $3 \mathrm{kn} / \mathrm{m}^{2}$ \\
\hline
\end{tabular}




\section{$3 \quad$ Modeling}

\subsection{Concrete Rigid Frame Structure System}

This system is used in the design of most residential buildings, so the loads carries by the slab, which is supported by beams (or beamless) on the columns then to the foundations. Walls here are partitions to separates building's components where its weight calculated, and it is applied as a distributed load on the beams, this allows mainly concentration loads on columns, moment and shear forces on the beams. The analysis results of the axial force were varied on the columns according to their share of loads, so the columns designed to have cross section of $(20 \times 20 \mathrm{~cm})$ with $4 \varnothing 12 \mathrm{~mm}$. Note that, the reinforcing percentage is the minimum value allowed by the code [5]. On the other hand, the concrete required for the columns is $3.0 \mathrm{~m}^{3}$ while all beams designed to have cross section of $(40 \times 20 \mathrm{~cm})$ and required concrete is $9.2 \mathrm{~m}^{3}$.

\subsection{Masonry Wall Bearing System}

In this model, no columns or beams have been modeled on the fact that the concrete masonry walls alone carry and support the roof load and other loads to the soil safely [8]. The values of the stresses on the walls have changed slightly through wall's height and the stress distribution has become more uniformly in the absence of columns and beams, where concentration of stress was occurred at interfaces between walls and columns or beams. Note that in the presence of openings, the stresses in the corners of the openings were slightly larger. Generally, concrete masonry wall bearing as structural system showed good behavior of carrying loads and stress distribution. Figure 3 illustrates the stresses in some of the selected wall's surfaces in the building.

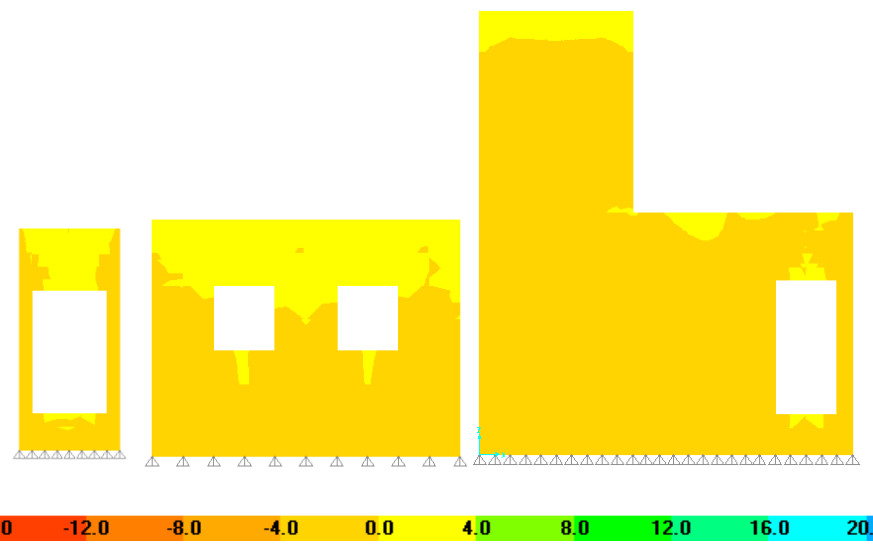

Figure 3: (a) Stresses in some of the selected wall's surfaces of the masonry wall-bearing model

\subsection{Composite (Mixed) model}

This model combines the first two models. The traditional way of building in the Libyan state is to embed walls in the concrete frames, where the walls are built then casting the columns

Proceedings of First Conference for Engineering Sciences and Technology (CEST-2018), vol. 2 
Simple and Sustainable Constipate to Save Cost and Time for Structure Constructions

and the roof. This method makes the wall an effective structural part (unintentionally) of carrying most of the load to the soil directly, resulting in a very large shortage of supporting forces through columns. As a result of the analysis, the axial force decreased from the column with the largest forces (comparing with first model) to become a load $40.58 \mathrm{kn}$ which is $10 \%$ of the designed load, while the other percentages of decrease in load on the rest of the other columns depending on the place in the building. Therefore, the $20 \times 20$ section is used with a minimum reinforce of $4 \varnothing 12 \mathrm{~mm}$, which is more than enough compared to loads on all columns. So the reinforced concrete required for the columns and beams as seam as in rigid frame structure system. Thus, masonry wall that embedded in the rigid frame carried $90 \%$ of the loads that is supposed to be carried by the columns.

\section{$4 \quad$ Results and Discussion}

The performance of the three systems was good for supporting and carrying the loads applied to them. The concrete rigid frame system is very effective if the implementation methodology is followed as provided for standards and codes. Nevertheless, because of the embedded of the masonry walls during the implementation made the structural elements in this system is highly inefficient and thus non-economic and non-sustainable due to waste of energy and materials in the construction and energy and the cost of recycling Table 3 summarizes the results.

Table 3: Normalized results of structural analysis and energy, cost estimations

\begin{tabular}{|c|c|c|c|c|c|}
\hline & \multirow{2}{*}{$\begin{array}{l}\text { Concrete Rigid } \\
\text { Frame System }\end{array}$} & \multirow{2}{*}{$\begin{array}{l}\text { Masonry Wall } \\
\text { Bearing System }\end{array}$} & \multirow{2}{*}{$\begin{array}{c}\text { Composite } \\
\text { System }\end{array}$} & \multicolumn{2}{|c|}{ Extreme differences (\%) } \\
\hline & & & & Min & Max \\
\hline $\overrightarrow{\tilde{\theta}}$ & 1.57 & 1 & 1.57 & - & 36 \\
\hline 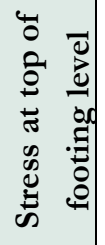 & 8 & 1 & 0.69 & 31 & 87.5 \\
\hline 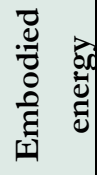 & 1.5 & 1 & 1.5 & - & 33 \\
\hline
\end{tabular}

Masonry wall system is respectable from an engineering field, and because the use of masonry walls is a basic concept in the housing of the Libyan state, where these walls used as partitions in the building, thus, it can use as structural elements as well. Hence that the wall capacity well 
demonstrated, so that the maximum stress did not exceed at the interface with soil $1.5 \mathrm{MPa}$ and gave a uniform and proportional distribution of loads to the entire building. The openings in the walls are somewhat in different form of the distribution of stress in the wall and caused a high concentration of stresses at the corners of these openings, whether for the doors or windows of the building. Concentrated stresses at the openings did not exceed 1.70 MPa. Thus, it is economy system compared to the other two systems. On the one hand, since building and construction, costs are determined mainly by the cost of materials, labor, framing, and placing or erection, and since the structural normal weight concrete cost is varying among countries and all over the world. However, for the Libya state it might be estimated $400 / \mathrm{m}^{3}$ Libyan dinar including $100 \mathrm{~kg}$ rebar [9].Moreover, the embodied energy of normal-weight reinforced concrete with $100 \mathrm{Kg}$ rebar per cubic meter is $2.12 \mathrm{MJ} / \mathrm{Kg}(0.56 \mathrm{kwh} / \mathrm{Kg})$ [10]. Therefore, using masonry wall bearing System leads to total saving resulting in cost non-use of normal-weight reinforced concrete $\left(12.2 \mathrm{~m}^{3}\right)$ is 4900 Libyan dinars, in addition to $26 \mathrm{Mwh}$ of the embodied energy. These values may be small at first sight, but it is represented cost of completely house in every 100 houses and is essentially important economically and environmentally if it is taken on an international scale.

\section{Conclusions}

Structural analysis and design using SAP200 and embodied energy, and cost estimation are performed to investigate the structural and energy performance. The results of the structural analysis showed good and effective performance for all studied systems. However, taking into consideration the economic and environmental aspects, the masonry wall bearing system model is the best performance. Where the maximum stress at the foundation level is small 1.5 $\mathrm{MPa}$, which makes it possible to build on the lowest bearing capacity of acceptable foundation soils types. In addition, uniformly distribution of the load on the walls is desirable from an engineering point of view to ensure that uniform behavior occurs because of compressing the foundation soil within the permissible limits. Furthermore, this system is economically good and can save $36 \%$ of the cost of building structural elements. This system requires less time and labor than other construction systems; also, this system is environmentally friendly. It uses as little construction material as possible. It can save $26 \mathrm{Mwh}$ of the embodied energy, as well as the possibility of recycling at the end building life span, because it is made of masonry that much easier in the grinding and recycle process compared to the reinforced concrete. Finally, the adoption of this system at an international level will achieve a perfect economic and environmental return.

\section{References}

[1] C. Russell Hibbeler. "Structural Analysis," Prentice Hall, N J, 2002.

[2] M. Nadim, "Structural concrete: theory and design, ” Prentice Hall, Inc. 2002

[3] International Code Council "International Building Code" IBC code, US, 2012

[4] American Society of Civil Engineers, “ASCE 7-10 Standard," VI, US, 2010

Proceedings of First Conference for Engineering Sciences and Technology (CEST-2018), vol. 2 
Simple and Sustainable Constipate to Save Cost and Time for Structure Constructions

[5] American concrete Institute, "Building Code Requirements for Structural Concrete," ACI Code 318-2011. American concrete Institute, MI, US. 2011

[6] M.A. Walker, "What about House Design and Room Location," Virginia Cooperative Extension, US.2009

[7] American Society of Civil Engineers, "Minimum Design Loads for Buildings and Other Structures,"

ASCE/SEI 7-10, NJ, US, 2010

[8] H. Fathy, "Architecture for the poor," The University of Chicago Press.US.1973.

[9] RC Means, "Means Cost Works," .July, 2011.http:// www.meanscostworks.com.

[10] Council on Tall Buildings and Urban Habitat, "Tall building in numbers," CTBUH Journal, Issue III, 50-51, 2009.

[11] Technical Manual Design for lifestyle and the future, "Australia's guide to environmentally sustainable homes". March.2010. http://www.yourhome.gov.au

[12] Technical Manual. Embodied Energy. June 2010. http://www.yourhome.gov.au/technical/ fs52.html

[13] AISC. "Designing for Sustainability," American Institute of Steel Construction.US, 2011 http:/ / www. aisc.org/ content.aspx?id=17560 